\title{
РОЗДІМ 4
}

\section{Макроекономічні механізми}

\section{Фактори впливу на стратегічне управління банківським ритейлом}

\author{
Т. А. ВАСИЛЬєвА , Я. М. КРИвичіi, І. О. ЛЕМшшіiі
}

\begin{abstract}
У статті розглянуто підходи до визначення «банківський ритейл», запропоновано трактувати його як окремий сегмент фінансового ринку щодо надання роздрібних банківських послуг із врахуванням потреб клієнтів. Здійснено аналіз сучасного стану роздрібного банківського бізнесу України за спектром основних продуктів та послуг, що відносяться до банківського ритейлу: послуги з використання платіжних карток, прийом та зарахування коштів на депозитний рахунок, споживче кредитування, іпотечні кредити, операції з обміну валюти, інші види розрахунковокасового обслуговування, оренда індивідуальних банківських сейфів. На основі аналізу сучасних каналів збуту банківського ритейлу визначено необхідність створення так званого «віртуального банку», без звичних офісів і відділень, та розвиток мобільних і онлайн-каналів збуту. Розглянуто основні фактори впливу на управління роздрібним банківським бізнесом (масове використання мережі Інтернет, глобалізаційні та інтеграційні процеси, посилення конкуренції між банками та небанківськими установами, технологічний розвиток, нові підходи до просування банківських продуктів) та встановлено ключову роль інформаційних та цифрових технологій у розвитку і функціонуванні банківського ритейлу. В статті виявлено основні проблеми стратегічного управління банківським ритейлом в Україні, проаналізовано досвід провідних країн світу щодо практичного впровадження інновацій у банківському ритейлі та перспективи їх застосування в Україні, у тому числі: розробка та впровадження програного забезпечення і цифрових платформ для автоматизації діяльності банку; застосування в діяльності банків децентралізованої технології блокчейн; технології з обробки та аналізу значних масивів інформації Big Data; технології використання смартфонів для здійснення різноманітних розрахунків Near Field Communication (NFC); технології біометрії для процедури ідентифікації; використання чат-ботів та віртуальних помічників для автоматизації процесів роботи з клієнтами.
\end{abstract}

Ключові слова: банківський ритейл, безготівковий розрахунок, дистрибуція, інновація, трансформація банків.

${ }^{i}$ Васильєва Тетяна Анатолівна, доктор економічних наук, професор, директор Навчально-наукового інституту фінансів, економіки та менеджменту імені Олега Балацького Сумського державного університету;

${ }^{i i}$ Кривич Яна Миколаївна, кандидат економічних наук, доцент кафедри фінансів, банківської справи та страхування Навчально-наукового інституту бізнес-технологій «УАБС» Сумського державного університету;

iii Леміш Інна Олександрівна, магістрант кафедри фінансів, банківської справи та страхування Навчальнонаукового інституту бізнес-технологій «УАБС» Сумського державного університету.

(C) Т. А. Васильєва, Я. М. Кривич, І. О. Леміш, 2018

https://doi.org/10.21272/mer.2018.80.04 
Tetyana A. Vasilyeva, Yana M. Kryvych, Inna O. Lemish. Factors Influencing Strategic Management of Banking Retail

Постановка проблеми. Роздрібний банківський бізнес $\epsilon$ одним із найприбутковіших напрямів в індустрії фінансових послуг. Разом із тим саме за цим напрямом спостерігається і чи не найбільший рівень конкуренції. Крім того, говорячи про ринок банківського ритейлу, варто відзначити і одну з ключових його проблем невисокий рівень довіри населення до банківської системи спричинений кризами 2008-2014 років, - що, у свою чергу, спровокувала незадовільний попит на банківські послуги. 3 урахуванням відзначеного особливої актуальності набувають питання пошуку оптимального механізму стратегічного управління банківським ритейлом та визначення факторів впливу на нього.

Аналіз останніх досліджень та публікацій. Аналіз наукових публікацій, присвячених дослідженню розвитку ринку банківських продуктів із сегменту ритейлу, показав, що вітчизняні та зарубіжні вчені приділяють велику увагу зазначеному питанню. Зокрема, багато уваги приділяється впровадженню інновацій у роздрібному банківському бізнесі, модифікації каналів продажу, цифровізації діяльності банківських установ, змінам моделей комунікацій 3 клієнтами, а також аналізу статистичних показників галузі. Ці та інші питання зазначеної проблематики у своїх працях досліджували такі зарубіжні науковці, як Ф. Абромсон, Л. Дансон, Р. Джозлін, К. Скіннер та інші. Дослідження в цьому науковому напрямі здійснювали і вітчизняні вчені, зокрема А. Буряк, Т. Васильєва, О. Вовчак, С. Сгоричева, А. Кузнєцова, С. Лсонов, А. Пересада, О. Чуб, Л. Шульгіна та інші науковців. Проте дослідження зазначеного кола авторів стосуються окремих аспектів банківського ритейлу i не розкривають комплексного аналізу чинників впливу на стратегічне управління банківським ритейлом, що і є кінцевою метою цієї статті.

Мета - дослідити сучасний стану роздрібного банківського бізнесу України та визначити фактори впливу на стратегічне управління банківським ритейлом.

Викладення основного матеріалу дослідження. Дослідження факторів впливу на стратегічне управління банківським ритейлом необхідно розпочати з розуміння сутності поняття «ритейл» та його складових. Аналіз науково-методичної літератури 3 визначеного питання показав, що на сьогодні не існує єдиного підходу до визначення поняття «ритейл». Найчастіше науковці розглядають «ритейл» із таких позицій, як: роздрібний продаж [7, 3]; принцип організації роздрібної торгівлі [4]; поштучний продаж товарів споживачам для кінцевого некомерційного використання і надання торговельних послуг $[4,5]$; комплекс послуг та продуктів для приватних споживачів $[6,9]$. У межах визначеного дослідження під поняттям «банківський ритейл» ми будемо розуміти окремий сегмент фінансового ринку щодо надання роздрібних банківських послуг із урахуванням потреб клієнтів.

Зауважимо, що сьогодні серед усіх напрямків банківського бізнесу ритейл є одним із найбільш прибуткових, оскільки комплекс послуг роздрібного банківського бізнесу фінансово-кредитні установи розглядають як джерело пасивів, комісійних, а також процентних доходів. Крім того, за умови ефективного стратегічного управління банківський ритейл є джерелом відносно дешевої ліквідності й високої прибутковості.

Найбільш поширений спектр послуг роздрібного банківського бізнесу наведений на рисунку 1.

Нині більшість економічно розвинених країн світу вже давно надають перевагу безготівковим розрахункам та поступово відмовляються від паперових грошей. В Україні здійснення безготівкових розрахунків та перехід до здійснення операцій 3 електронними грошима перебувають у стадії розвитку. 


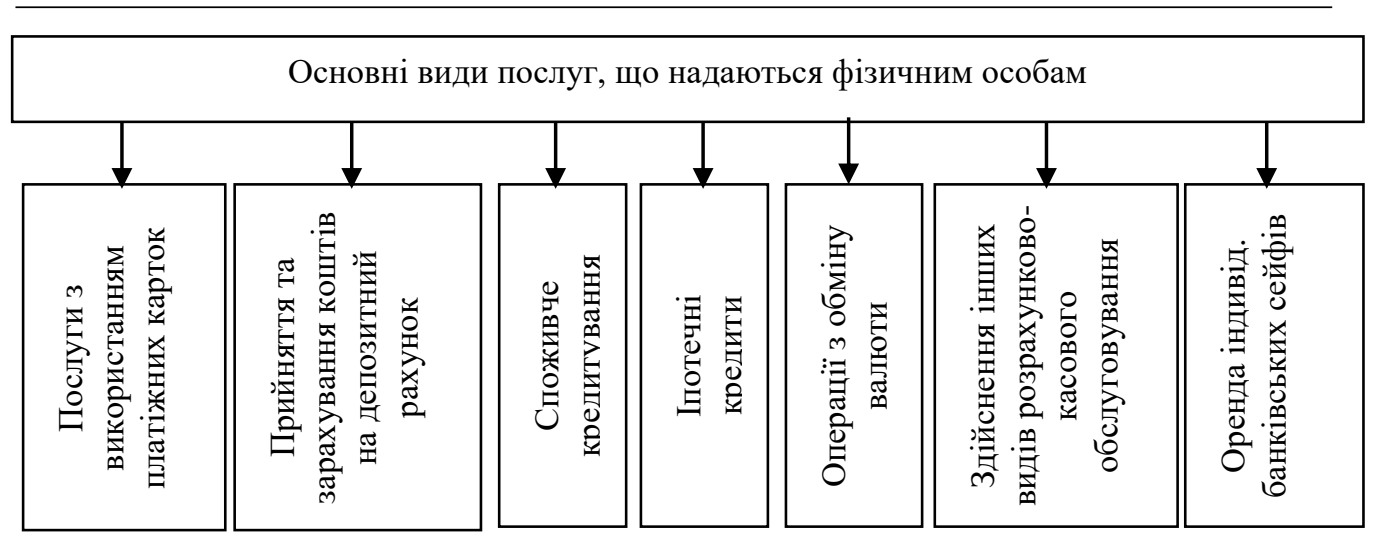

Рис. 1. Послуги роздрібного банківського бізнесу [1]

За перше півріччя 2018 року було випущено 41,3 млн грн електронних грошей; щодо обсягу операцій з електронними грошима, то він становив 3072 млн грн; кількість е-гманців з електронними грошима за перше півріччя 2018 року зафіксована на рівні 56,8 млн шт.

Наразі такі банки здійснюють випуск та операції 3 електронними грошима: «ТАСКОМБАНК», «АЛЬФА-БАНК», «ПРИВАТБАНК», Банк «ВОСТОК», «ПУМБ», «ОЩАДБАНК» (MasterCard)»; «ОЩАДБАНК», «ПУМБ», «ПРИВАТБАНК» (VISA); «УКРГАЗБАНК», «ЮНЕКС БАНК», «ПРАВЕКС БАНК», «ПОЛІКОМБАНК» (НПС «ПРОСТІР»); «ТАСКОМБАНК» (МАХІ); «КБ «ГЛОБУС» (GlobalMoney); «АЛЬФАБАНК» (FORPOST) [8].

За результатами першого півріччя 2018 року частка обсягу безготівкових операцій підвищилася до 44,1 \% (порівняно з 38,3 \% за перше півріччя 2017 року).

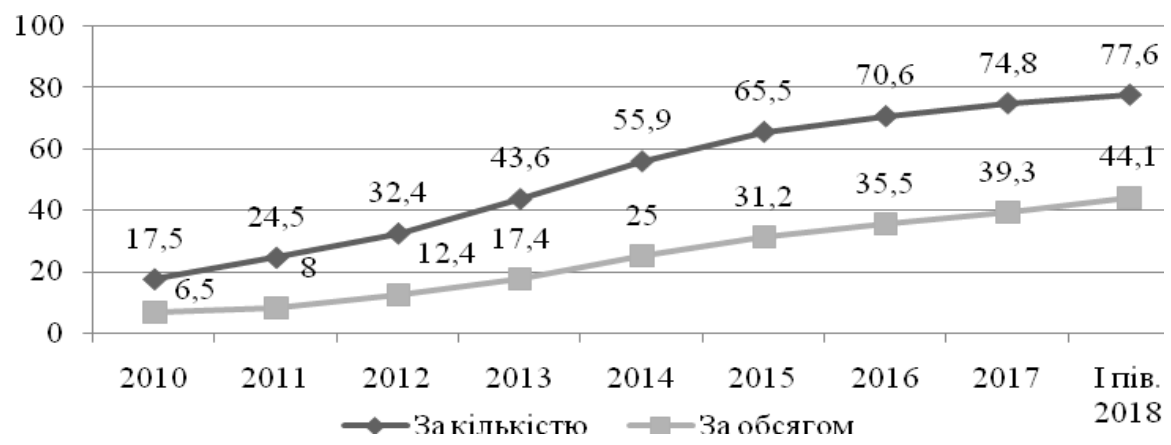

Рис. 2. Частка безготівкових операцій від усіх операцій, здійснених із використанням платіжних карток, \% [10]

Обсяги безготівкових операцій за перше півріччя 2018 року розподілилися так:

- операції у мережі Інтернет - 36,4% (середній чек становить 380 грн);

- $\quad$ операції переказу коштів із картки на картку - 31,1 \% (середній чек - 1583 грн);

- розрахунки у торговельній мережі - 29,9 \% (середній чек - 233 грн); 
Tetyana A. Vasilyeva, Yana M. Kryvych, Inna O. Lemish. Factors Influencing Strategic Management of Banking Retail

- $\quad$ операції у пристроях самообслуговування - 2,6 \% (середній чек - 557 грн) [10].

У загальній структурі (пунктах) здійснених безготівкових операцій із платіжними картками найбільшу частку $(51,7 \%)$ мають розрахунки у торговельній мережі.

Загальна кількість платіжних карток в Україні станом на 1 липня 2018 року становила 60,1 млн шт., з яких майже 35,3 млн шт. - активних (58,7 \%) (табл. 1).

Наразі загальна кількість банків-учасників карткових платіжних систем становить 77 (порівняно з 128 станом на 01.01.2015 р., що пов'язано зі скороченням загальної кількості банків).

Таблиия 1

Дані у розрізі 10 банків-учасників платіжних систем щодо кількості платіжних карток та інфраструктури їх обслуговування станом на 01.07.2018 р. [2]

\begin{tabular}{|c|c|c|c|c|c|}
\hline \multirow[b]{2}{*}{ Назва банку } & \multicolumn{5}{|c|}{ Кількість (штук, одиниць) } \\
\hline & $\begin{array}{c}\text { платіжних } \\
\text { карток } \\
\text { (в обігу) }\end{array}$ & $\begin{array}{c}\text { плат. } \\
\text { карток } \\
\text { (активні) }\end{array}$ & $\begin{array}{c}\text { банківських } \\
\text { пристроїв } \\
\text { само- } \\
\text { обслуговування }\end{array}$ & $\begin{array}{l}\text { платіжних } \\
\text { терміналів }\end{array}$ & $\begin{array}{c}\text { підприємств } \\
\text { торгівлі } \\
\text { та сфери } \\
\text { послуг } \\
\end{array}$ \\
\hline $\begin{array}{c}\text { АТ КБ } \\
\text { «ПРИВАТБАНК» }\end{array}$ & 29717752 & 19790959 & 19860 & 158767 & 100755 \\
\hline $\begin{array}{c}\text { АТ } \\
\text { «ОЩАДБАНК» }\end{array}$ & 11024787 & 5806890 & 6200 & 47533 & 35712 \\
\hline $\begin{array}{c}\text { АТ «Райффайзен } \\
\text { Банк Аваль» }\end{array}$ & 4864234 & 2211297 & 2901 & 26101 & 19521 \\
\hline АТ «УкрСиббанк» & 2264982 & 1055336 & 1127 & 5517 & 4677 \\
\hline ПАТ «ПУМБ» & 2259424 & 750286 & 700 & 3860 & 3304 \\
\hline $\begin{array}{c}\text { ПАТ «АЛЬФА- } \\
\text { БАНК» }\end{array}$ & 1965768 & 1766742 & 367 & 345 & 11 \\
\hline АТ «А - БАНК » & 1062715 & 548542 & 0 & 179 & 0 \\
\hline $\begin{array}{c}\text { АБ } \\
\text { «УКРГАЗБАНК» }\end{array}$ & 790889 & 368881 & 678 & 1370 & 963 \\
\hline АТ «ОТП БАНК» & 666113 & 321781 & 139 & 382 & 122 \\
\hline $\begin{array}{c}\text { АТ } \\
\text { «Укрексімбанк» }\end{array}$ & 650471 & 340640 & 656 & 3325 & 2535 \\
\hline $\begin{array}{c}\text { Усього } \\
\text { (по } 82 \text { банках) } \\
\end{array}$ & 60125026 & 35299076 & 36495 & 270522 & 187708 \\
\hline
\end{tabular}

Щодо відділень та філій банків України станом на перше жовтня 2018 року в загальній кількості (81 банк) має 8760 діючих структурних підрозділів.

Загальна кількість банкоматів в Україні становить 18,5 тис. шт.

За перше півріччя 2018 року мережа платіжних терміналів зросла до 270,5 тис. шт.

Показник співвідношення кількості платіжних терміналів до кількості постійного населення України станом на 1.07.2018 року дорівнює 6,4 шт. на 1 тисячу населення. Лідерами серед областей України, де кількість платіжних терміналів на 1 тисячу населення перевищує середній показник в Україні, були: Дніпропетровська, Київська та Одеська області (табл. 2). Найнижчі показники спостерігалися у Луганській та Донецькій областях. 
Т. А. Васильєва, Я. М. Кривич, І. О. Леміш.

Фактори впливу на стратегічне управління банківським ритейлом

Таблиия 2

Дані в регіональному розрізі щодо кількості платіжних карток та інфраструктури їх обслуговування станом на 01.07.2018 р. [12]

\begin{tabular}{|c|c|c|c|c|}
\hline \multirow[b]{2}{*}{ Назва області } & \multicolumn{4}{|c|}{ Кількість ( штук, одиниць) } \\
\hline & $\begin{array}{c}\text { платіжних } \\
\text { карток } \\
\text { (в обігу) }\end{array}$ & $\begin{array}{c}\text { банківських } \\
\text { пристроїв } \\
\text { самообслуговування }\end{array}$ & $\begin{array}{l}\text { платіжних } \\
\text { терміналів }\end{array}$ & $\begin{array}{c}\text { підприємств } \\
\text { торгівлі та } \\
\text { сфери } \\
\text { послуг } \\
\end{array}$ \\
\hline Вінницька & 1619247 & 1275 & 6997 & 5222 \\
\hline Волинська & 1073843 & 789 & 5617 & 3552 \\
\hline Дніпропетровська & 7758439 & 3719 & 28095 & 19630 \\
\hline Донецька & 2953429 & 1567 & 11389 & 7998 \\
\hline Житомирська & 1305267 & 1083 & 6780 & 4751 \\
\hline Закарпатська & 1020934 & 822 & 4350 & 3093 \\
\hline Запорізька & 2441567 & 1673 & 12362 & 8143 \\
\hline Івано-Франківська & 1302706 & 930 & 6362 & 4485 \\
\hline Київська & 3055152 & 780 & 14520 & 10197 \\
\hline Кіровоградська & 1034167 & 814 & 5790 & 4027 \\
\hline Луганська & 1014914 & 519 & 3379 & 2407 \\
\hline Львівська & 3878477 & 1974 & 15359 & 9959 \\
\hline Миколаївська & 1384041 & 1170 & 7388 & 5423 \\
\hline Одеська & 3663871 & 2209 & 17657 & 12074 \\
\hline Полтавська & 1892944 & 1487 & 10208 & 7421 \\
\hline Рівненська & 1135846 & 845 & 5153 & 3521 \\
\hline Сумська & 1441820 & 1086 & 6722 & 5161 \\
\hline Тернопільська & 905222 & 751 & 3743 & 2496 \\
\hline Харківська & 4168344 & 2482 & 18665 & 12184 \\
\hline Херсонська & 1126797 & 1048 & 6980 & 5079 \\
\hline Хмельницька & 1427225 & 1040 & 6370 & 4725 \\
\hline Черкаська & 1428640 & 1146 & 7586 & 5233 \\
\hline Чернівецька & 831879 & 640 & 3644 & 2060 \\
\hline Чернігівська & 1145862 & 866 & 5801 & 4117 \\
\hline Київ & 11114393 & 5780 & 49605 & 34750 \\
\hline Усього & 60125026 & 36495 & 270522 & 187708 \\
\hline
\end{tabular}

Попри наявні проблеми в економіці, та значний рівень інфляції, кредитування для банків все одно залишається одним із головних способів отримання прибутку.

Наприкінці 2017 року та у I кварталі 2018 року всі банки, які мали можливість, вийшли на ринок споживчого кредитування. Близько половини банків у I кварталі продовжували нарощувати кредити населенню.

Також розглядаючи роздрібне банківське кредитування у розрізі груп банків за перший квартал 2018 року, варто сказати, що лідерство за обсягами видачі позик належить іноземним банками (АТ «Райффайзен Банк Аваль», «ОТП Банк» та інші) та АТ КБ «ПРИВАТБАНК».

Концентрація кредитів фізичним особам була досить високою - на 5 банків припадало 65 \% загального портфеля сектору.

Щодо валових гривневих кредитів, що надавалися фізичним особам, то в цілому це були позики на придбання побутової техніки, автомобілів та інші споживчі цілі. 
Враховуючи високу швидкість обертання, частка нових кредитів на поточні потреби в нових видачах залишається домінуючою - 98 \% [4].

Найвища концентрація була наявна в сегменті автокредитування, оскільки 5 банків займали $80 \%$ ринку.

Зважаючи на нестабільність валютного курсу впродовж останніх трьох років, у структурі переважають гривневі кредити.

Щодо ситуації на депозитному ринку, то рівень валютних депозитів також залишається низьким, оскільки процентні ставки за депозитами в іноземній валюті до цього часу перебувають на історичних мінімумах (становлять $3,4 \%$ за річними вкладами фізичних осіб у доларах). Гривневі вклади домогосподарств на вимогу наразі практично не надають процентних доходів вкладникам.

Темпи приросту депозитів у цьому році мають потенціал до прискорення з огляду на зростання номінальних доходів населення в Україні.

До першої п'ятірки за банківськими вкладами фізичних осіб увійшли АБ «Укргазбанк», АТ «Ощадбанк», ПАТ « ПУМБ», «ОТП Банк» та «Альфа-Банк» [10].

Рівень довіри до фінансово-кредитних установ, якість обслуговування, а також технологічна доступність продуктів відіграють усе більшу роль у залученні коштів банками. Тому великі банківські установи 3 іноземним капіталом продовжують нарощувати депозитну базу, хоча і пропонують низькі ставки за депозитами. А от банкам із російським капіталом залучати ресурси не допомагають навіть значно вищі за ринкові депозитні ставки. Значна частина вкладників надалі тримає кошти в державних банках, слабко реагуючи на зниження ними відсоткової ставки.

Кожний комерційний банк формує власну систему ритейлу, враховуючи власну стратегію та досвід роботи на банківському ринку, беручи до уваги можливості та прогнози на перспективу. Безпосереднє формування продуктового ряду банківського ритейлу здійснюється за результатами всебічного вивчення потреб приватних споживачів у фінансових послугах та повинно включати комплексні продукти, що цілком задовольнятимуть такі потреби.

Щодо світової практики організації банківського ритейлу, виділяють три рівні: перший - передбачає структурне виокремлення роздрібного бізнесу в середині універсального банку як окремого напрямку діяльності фінансово-кредитної установи; другий - передбачає виділення роздрібного бізнесу в окрему організаційну складову в структурі банківської групи; третій - створення вузькоспеціалізованого незалежного банку, робота якого полягає лише в наданні послуг банківського ритейлу [1].

В Україні більшою популярністю користується перший рівень організації банківського ритейлу.

В сучасних умовах розвитку технологій та впровадження інновацій більшого обговорення набуває питання про необхідність створення так званого «віртуального банку» без звичних для нас офісів, відділень та створення мобільних та онлайн-каналів збуту. Наразі створення в Україні «віртуального банку» неможливе, враховуючи нормативні вимоги НБУ щодо організації банківської діяльності.

Посилення процесів цифровізації банківської діяльності в Україні призводить до появи нових методів обробки та збереження, а також передачі банківських даних; збільшення потужності та швидкості їх обробки призвело до зміни процесів залучення нових клієнтів, поширення банківських продуктів та послуг і організації відповідних бізнес-процесів банку. 
Т. А. Васильєва, Я. М. Кривич, І. О. Леміш.

Фактори впливу на стратегічне управління банківським ритейлом

Цифровізація банківництва в нашій країні зумовлює більш грунтовне дослідження впливу інформаційних технологій на грошові потоки фінансово-кредитної установи, оскільки цей процес змінив систему фінансових відносин між учасниками ринку банківських послуг, збільшив рівень конкуренції на сегментах цього ринку та залучив на ринок паралельно 3 небанківськими фінансово-кредитними установами високотехнологічні компанії і так звані стартапи «Fintech».

Нині, банки України поки що тільки частково впроваджують цифрові технологій у власну діяльність. У своїй роботі банківські установи вже використовують «цифровий банківський бренд», «банкінг як сервіс» та «інклюзивний банкінг».

Наразі в Україні широко використовують Digital Marketing - як технологію, що дозволяє всіляко поширювати банківські продукти для великої кількості клієнтів, мінімізуючи при цьому витрати банку щодо залучення нових споживачів. Це здійснюється за допомогою інтернет-сайтів, банерної реклами, соціальних мереж, контекстної реклами тощо.

В усіх економічно розвинених країнах значна увага приділяється розробленню та впровадженню програмного забезпечення, цифрових платформ, що б дозволило більше автоматизувати діяльність банку, допомагало управляти взаємовідносинами одночасно і 3 клієнтами та бізнес-процесами банківської установи [2].

Також останнім часом у нашій країні все більше банків починають розглядати децентралізовану фінансову систему блокчейн як стратегічний інструмент, що в подальшому зможе значно спростити і кардинально змінити банківську систему. За допомогою блокчейну можна буде створювати електронний обіг усієї документації без додаткових провайдерів, здійснювати обіг криптовалюти, а також посилювати захист банківських рахунків тощо.

Ще однією новою інновацією у фінансовій сфері можна вважати Big Data технологію 3 обробки значних масивів інформації 3 подальшим іiі аналізом. Ця технологія допоможе банкам оперативно та без значних втрат коштів здійснювати пошук та розроблення персональних пропозицій клієнтам відповідно до їх потреб та рівня платоспроможності, захищатися від шахрайства, сприятиме активізації продажу продуктів та послуг.

Великою популярністю в провідних країнах світу користується Near Field Communication (NFC). Така технологія передбачає використання смартфонів при здійсненні різноманітних розрахунків, чим відміняе потребу від використання платіжних карток. В Україні наразі ця технологія не користується значною популярністю, оскільки ще велика частина населення надає перевагу використанню готівки.

Серед останніх розробок науковців усе більшої уваги набуває використання технології біометрії. Такі засоби ідентифікації власника цілком можна використовувати i в банківській сфері, адже це б посилювало рівень безпеки здійснення операцій, i довіру до банку.

За кордоном стало можливим використання чат-ботів та віртуальних помічників для поліпшення роботи банківським працівникам у зв'язку з автоматизацією різних процесів: спілкування з клієнтами банку щодо стану рахунку, або, наприклад, специфіки банківського продукту чи послуги. Використання роботів в банківський сфері дозволило б цілодобово надавати допомогу клієнтам, здійснювати консультаційні послуги тощо. 
Tetyana A. Vasilyeva, Yana M. Kryvych, Inna O. Lemish. Factors Influencing Strategic Management of Banking Retail

Саме від менеджменту банку, виходячи з фінансових можливостей і обраної моделі стратегічного розвитку фінансово-кредитної установи, залежить можливість впровадження різноманітних цифрових технологій, що дозволять вирішити різні проблеми його діяльності, оптимізувати доходи та витрати, підвищити ефективність функціонування банку.

Враховуючи вплив новітніх технологій в останні десять років на розвиток та функціонування банківського ритейлу, доцільно виокремити такі фактори впливу:

1. Масове використання мережі Інтернет та поступовий перехід фінансового сектору в онлайн-режим. Наразі все більша кількість населення та підприємств України використовує Інтернет для оперативного отримання, опрацювання та передачі необхідної інформації, здійснення купівлі та продажу.

2. Глобалізаційні та інтеграційні процеси впливають на рівень конкуренції на банківському ринку України, вимагають впровадження нових технологій, поліпшення якості продуктів та послуг.

3. Посилення конкуренції між банками та небанківськими установами через універсалізацію їх діяльності, надання останніми таких послуг, як наприклад, кредитування або ж здійснення онлайн-платежів чи переказу коштів.

4. Технологічний розвиток вимагає від банківських установ оперативного управління, забезпечення банків необхідною кількістю центрів самообслуговування, розроблення та адаптації нових технологічних платформ.

5. Посилення конкурентної боротьби вимагає підвищення ефективності роботи щодо просування продуктів та послуг, а саме - використання та удосконалення реклами як одного з чинників впливу на репутацію банку; адаптація фронт-офісу до потреб та очікувань клієнта; використання мобільних технологій як одного зі способів самообслуговування, розроблення та впровадження різних мобільних додатків; підвищення рівня сервісу; оптимізації витрат банку тощо.

Таким чином, стратегічне управління банківським ритейлом передбачає пошук, розроблення та ефективне використання нових технологій, оперативне прийняття управлінських рішень в умовах мінливості кон'юнктури ринку, посилення суперницької боротьби між фінансово-кредитними та небанківськими установами, зміни потреб клієнтів, а також пропозицій основних конкурентів.

Висновки та перспективи подальших наукових розробок. Підбиваючи підсумки 3 проведеного дослідження, підкреслимо, по-перше, що ринок роздрібних банківських послуг динамічно розвивається, тому 3 метою утримання конкурентних переваг банківські установи мають постійно удосконалювати власну продуктову лінійку, яка, у свою чергу, повинна відповідати запитам ринку. По-друге, основою розвитку банківського бізнесу на сьогодні $є$ інформаційні технології. Тому при формуванні стратегічних планів не можна нехтувати процесами діджиталізації банківського бізнесу. Розвиток мобільних додатків, оптимізація дистанційного обслуговування клієнтів, запровадження «банків без відділень» - усе це залишається ключовими завданнями для управління фінансово-кредитними установами для збереження власних позицій на банківському ринку та динамічного розвитку власної діяльності. По-третє, постійно зростаючий рівень конкуренції з боку небанківських гравців, зокрема різного роду фінтех-компаній, вимагає розроблення можливих механізмів кооперації. Саме на грунтовне дослідження визначених складових будуть спрямовані подальші дослідження авторів. 


\title{
Література
}

1. Банківська справа: організація діяльності комерційного банку / за ред. Г. Н. Бєлоглазова, Л. П. Кроливецької. Банківська справа : підручник / за ред. Г. Н. Бєлоглазова, Л. П. Кроливецької. - 5-те вид., перероб. і доп. - Москва : Фінанси і статистика, 2003. - 592 с.

2. Гребенюк, Н. В. Стратегічне управління банком в контексті трансформації банківської системи України : дисертація на здобуття наукового ступеня кандидата економічних наук: спец. 08.00.08 - Гроші, фінанси і кредит / Гребенюк Надія Василівна. - К., 2018. - 328 с.

3. Демченко, А. М. Економічна сутність ритейлу в банківському секторі України та можливості його вдосконалення / А. М. Демченко // Регіональна економіка. - 2015. - № 3. - С. 101-108.

4. Демченко, А. М. Сучасний стан банківського ритейлу в Україні / А. М. Демченко // Фінансовий простір. - 2014. - № 3(15). - С. 48-52.

5. Звіт Національного банку України Про фінансову стабільність (червень 2018) [Електронний pecypc]. - Режим доступу : https://bank.gov.ua/doccatalog/document?id=71475860.

6. Кириленко, $C$. Зміна парадигми продажу банківських послуг в умовах розвитку цифрових каналів дистрибуції / С. Кириленко // Світ фінансів. - 2016. - № 4(49). - С. 140-147.

7. Лапко, О. О. Інноваційні механізми ритейлу в банківському секторі України / О.О.Лапко, А. М. Демченко // Фінансово-кредитна діяльність: проблеми теорії та практики. - 2014. Вип. 2. - С. 65-72.

8. Операції банків України з електронними грошима [Електронний ресурс]. - Режим доступу : https://bank.gov.ua/control/uk/publish/article?art_id=125412\&cat_id=22918283.

9. Пантєлєєва, $H$. Полівекторність інновацій роздрібного бізнесу: реалії сьогодення / Н. Пантєлєєва // Вісник НБУ. - 2013. - № 5. - С. 15-21.

10. Рейтинг банків: як почувалися фінустанови в I кварталі 2018 р. [Електронний ресурс]. Режим доступу: https://mind.ua/publications/20184781-rejting-bankiv-yak-pochuvalisyafinustanovi-v-i-kvartali-2018-roku.

11. Ринок платіжних карток України: статистична інформація НБУ [Електронний ресурс]. Режим доступу : https://bank.gov.ua/control/uk/publish/article?art_id=75700271.

12. Статистичні дані НБУ щодо ринку платіжних карток [Електронний ресурс]. - Режим доступу : https://bank.gov.ua/control/uk/publish/category?cat_id=79219.

Отримано 28.08.2018 p.

Факторы влияния на стратегическое управление банковским ритейлом

\section{ТАТЬЯНА АНАТОЛЬЕВНА ВАСИЛЬЕВА*, ЯНА НИКОЛАЕВНА КРИВИч**, ИННА АЛЕКСАНДРОвНА ЛЕМИШ ${ }^{* * *}$}

\author{
* доктор экономических наук, профессор, директор \\ Учебно-научного института финансов, экономики и менеджмента имени Олега Балачкого \\ Сумского государственного университета, \\ ул. Римского-Корсакова, 2, г. Сумы, 40007, Украина, \\ тел.: 00-380-542-335474,e-mail:tavasilyeva@fem.sumdu.edu.ua \\ ** кандидат экономических наук, дочент кафедры финансов, банковского дела и \\ страхования Учебно-научного института бизнес-технологий «УАБД» \\ Сумского государственного университета, \\ ул. Петропавловская, 57, г. Сумы, 40000, Украина, \\ тел.: 00-380-542-665089, e-mail: y.kryvych@uabs.sumdu.edu.ua
}




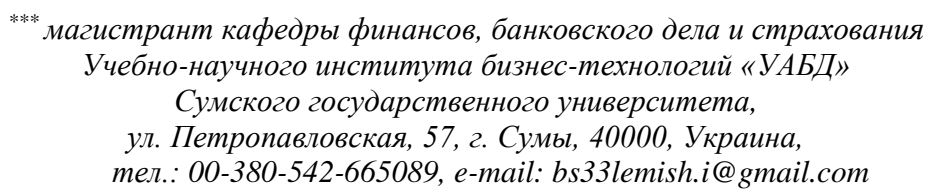

В статье рассмотрены подходы к определению «банковский ритейл», предложено трактовать его как отдельный сегмент финансового рынка по предоставлению розничных банковских услуг с учетом потребностей клиентов. Осуществлен анализ современного состояния розничного банковского бизнеса Украины по спектру основных продуктов и услуг, относящихся к банковскому ритейлу: услуги по использованию платежных карт, прием и зачисление средств на депозитный счет, потребительское кредитование, ипотечные кредиты, операции по обмену валюты, другие виды расчетно-кассового обслуживания, аренда индивидуальных банковских сейфов. На основе анализа современных каналов сбыта банковского ритейла определена необходимость создания так называемого «виртуального банка», без привычных офисов и отделений, и развитие мобильных и онлайн-каналов сбыта. Рассмотрены основные факторы влияния на управление розничным банковским бизнесом (массовое использование сети Интернет, глобализационные и интеграционные процессы, усиление конкуренции между банками и небанковскими учреждениями, технологическое развитие, новые подходы к продвижению банковских продуктов) и установлено ключевую роль информационных и цифровых технологий в развитии и функционировании банковского ритейла. В статье выявлены основные проблемы стратегического управления банковским ритейлом в Украине, проанализирован опыт ведущих стран мира по практическому внедрению инноваций в банковском ритейле и перспективы их применения в Украине, в том числе: разработка и внедрение проигранного обеспечения и цифровых платформ для автоматизации деятельности банка; применение в деятельности банков децентрализованной технологии блокчейн; технологии по обработке и анализу больших массивов информации Big Data; технологии использования смартфонов для осуществления различных расчетов Near Field Communication (NFC); технологии биометрии для процедуры идентификации; использование чат-ботов и виртуальных помощников для автоматизации процессов работы с клиентами.

Ключевые слова: банковский ритейл, безналичный расчет, дистрибуция, инновация, трансформация банков.

\section{Mechanism of Economic Regulation, 2018, No 3, 55-65 \\ ISSN 1726-8699 (print)}

Factors Influencing Strategic Management of Banking Retail

\section{Tetyana A. Vasilieva*, YANA M. KRYVYCH*, INNA O. LEMISH ${ }^{* * *}$}

* Dr. (Economics), Professor, Director of the Educational and Scientific Institute of Finance, Economics and Management named after Oleg Balatsky Sumy State University, R.-Korsakova Str., 2, Sumy, 40007, Ukraine, phone:00-380-542-335474, e-mail:tavasilyeva@fem.sumdu.edu.ua

${ }^{*}$ C.Sc. (Economics), Associate Professor, Department of Finance, Banking and Insurance, Education and Research Institute for Business Technologies «UAB», Sumy State University, 
Т. А. Васильєва, Я. М. Кривич, І. О. Леміш.

Фактори впливу на стратегічне управління банківським ритейлом

\author{
Petropavlivska Str., 57, Sumy, 40000, Ukraine, \\ phone: 00-380-542-665089,e-mail: y.kryvych@uabs.sumdu.edu.ua \\ **** Master student Department of Finance, Banking and Insurance, Education and Research \\ Institute for Business Technologies «UAB», Sumy State University, \\ Petropavlivska Str., 57, Sumy, 40000, Ukraine, \\ phone:00-380-542-665089,e-mail: bs33lemish.i@gmail.com
}

Manuscript received 28 August 2018

The article deals with the approaches to the definition of "banking retail", it is proposed to treat it as a separate segment of the financial market for the provision of retail banking services, taking into account the needs of clients. The authors carried out the analysis of the current state of the retail banking business in Ukraine by the range of the main products and services related to the banking retail: operations with payment cards, servicing of deposit accounts, consumer lending, mortgage loans, currency exchange transactions, other types of settlement and cash services, lease of individual safe deposit boxes. On the basis of the analysis of modern marketing channels of retail banking, the necessity of formation a so-called "virtual bank", without the usual offices and affiliates, and the development of mobile and online sales channels was proved. The main factors influencing the management of retail banking business (mass internet usage, globalization and integration processes, strengthening of competition between banks and non-banking institutions, technological development, new approaches to the promotion of banking products) were considered, and the key role of information and digital technologies in the development and functioning of banking retail was determined. The article reveals the main problems of strategic management of retail banking in Ukraine, analyzes the experience of leading countries in the field of practical application of innovations in banking retail and their prospects in Ukraine, including: development and implementation of software and digital platforms for automation of the banking business; application of decentralized technology blockchain in the activities of banks; application of technology Big Data for handling and analyzing large bulk data sets; application of technology Near Field Communication (NFC) for using smartphones for various settlements; biometric technology for the identification procedure; the use of chat bots and virtual assistants to automate the customer services.

Keywords: bank retail, non-cash payments, distribution, innovation, bank transformation.

JEL Code: E44

Tables: 2; Figures: 2; References: 12

Language of the article: Ukrainian

References

1. Byeloglazova, G. N. \& Kroly`veczkoj, L. P. (2003). Bankivs`ka sprava: organizaciya diyal’nosti komercijnogo banku [Banking: organizing the activities of a commercial bank]. Moskva: Finansy` i staty`sty`ka, 592.

2. Grebenyuk, N. V. (2018). Strategichne upravlinnya bankom v konteksti transformaciyi bankivs koyi sy stemy Ukrayiny [Strategic management of the bank in the context of the transformation of the banking system of Ukraine]. Kyiv, 328.

3. Demchenko, A. M. (2015). Ekonomichna sutnist` ritejlu v bankivs`komu sektori Ukrayiny` ta mozhly`vosti jogo vdoskonalennya [The economic essence of retail in the banking sector of Ukraine and the possibilities for its improvement]. Regional 'na ekonomika, 3, 101-108.

4. Demchenko, A. M. (2014). Suchasny`j stan bankivs`kogo ry`tejlu v Ukrayini [The current state of bank retail in Ukraine]. Finansovy j prostir, 3(15), 48-52.

5. Zvit Nacional'nogo banku Ukrayiny`Pro finansovu stabil'nist` (cherven`2018) [Report of the National Bank of Ukraine on Financial Stability (June 2018)]. Retrieved from https://bank.gov.ua/doccatalog/document?id=71475860. Available 28.08.2018. 
6. Ky`ry`lenko, S. (2016). Zmina parady`gmy` prodazhu bankivs`ky`x poslug v umovax rozvy`tku cy`frovy`x kanaliv dy`stry`buciyi [Changing the paradigm of selling banking services in the development of digital distribution channels]. Svit finansiv, 4(49), 140-147.

7. Lapko, O. O. (2014). Innovacijni mexanizmy` ry`tejlu v bankivs`kmu sektori Ukrayiny` [Innovative mechanisms of retail in the banking sector of Ukraine]. Finansovo-kredy'tna diyal'nist': problemy' teoriyi ta prakty`ky, 2, 65-72.

8. Operatsii bankiv Ukrainy z elektronnymy hroshyma [Operations of Ukrainian banks with electronic money]. $\quad$ Retrieved https://bank.gov.ua/control/uk/publish/article?art_id=125412\&cat_id=22918283. Available 06.09.2018.

9. Pantyelyeyeva, N. (2013). Polivektornist innovacij rozdribnogo biznesu: realiyi s`ogodennya [Polyvectorality of retail business innovation: the realities of today]. Visny $k N B U, 5,15-21$

10. Rejty`ng bankiv: yak pochuvaly`sya finustanovy` v I kvartali 2018 [Rating of banks: how did the financial institutions feel in the first quarter of 2018]. Retrieved from https://mind.ua/publications/20184781-rejting-bankiv-yak-pochuvalisya-finustanovi-v-i-kvartali2018-roku. Available 30.09.2018.

11. Ry`nok platizhny`x kartok Ukrayiny`s staty`sty`chna informaciya NBU [Market of payment cards of Ukraine: statistical information of the NBU]. Retrieved from https://bank.gov.ua/control/uk/publish/article?art_id=75700271.

12. Staty`sty`chni dani NBU shhodo ry`nku platizhny`x kartok [Statistical data of the NBU on the $\begin{array}{llll}\text { market of } & \text { payment } & \text { Retrieved }\end{array}$ https://bank.gov.ua/control/uk/publish/category?cat_id=79219. 